\title{
Marinospirillum celere sp. nov., a novel haloalkaliphilic, helical bacterium isolated from Mono Lake
}

\author{
Zorigto Namsaraev, ${ }^{1}$ Vladimir Akimov, ${ }^{2}$ Alexandre Tsapin, ${ }^{3}$ \\ Ekaterina Barinova, ${ }^{1}$ Kenneth Nealson ${ }^{4}$ and Vladimir Gorlenko ${ }^{1}$ \\ ${ }^{1}$ Winogradsky Institute of Microbiology RAS, 117312, pr. 60-letiya Oktyabrya 7/2, Moscow, Russia \\ ${ }^{2}$ Skryabin Institute of Biochemistry and Physiology of Microorganisms RAS, 142290 Pushchino, \\ Moscow Region, Russia \\ ${ }^{3}$ NASA, Jet Propulsion Laboratory, California Institute of Technology, Pasadena, CA 91109, USA \\ ${ }^{4}$ University of Southern California, Los Angeles, CA 90089, USA
}

Correspondence

Zorigto Namsaraev zorigto@gmail.com
Two strains of a Gram-negative, helical, haloalkaliphilic bacterium were isolated from Mono Lake (USA). Both strains were mesophilic and grew between 13 and $55^{\circ} \mathrm{C}$, with optimum growth at $35-45^{\circ} \mathrm{C}$. The optimum $\mathrm{pH}$ for growth was 9.5 . Growth was observed at $\mathrm{NaCl}$ concentrations of $0.5-12 \%(\mathrm{w} / \mathrm{v})$, with optimum growth at $2 \% \mathrm{NaCl}$. Both isolates were motile by means of bipolar tuft flagella, coccoid body-forming and strictly aerobic. It was concluded that they belong to the same species, based on DNA-DNA hybridization values (95\% DNA relatedness). DNA G+C contents of the novel strains were 52.1 and 52.3 mol\%. On the basis of 16S rRNA gene sequence similarity, both strains were shown to be related closely to the members of the genus Marinospirillum (family Oceanospirillaceae, class Gammaproteobacteria). Sequence similarity of strain v1c_Sn-red ${ }^{\top}$ to the type strains of Marinospirillum alkaliphilum, Marinospirillum minutulum, Marinospirillum megaterium and Marinospirillum insulare was 95.0, 92.7, 91.8 and 91.8\%, respectively. Chemotaxonomic data [major ubiquinone, Q8; major fatty acids, $\mathrm{C}_{18: 1}(\mathrm{n}-7)$ and $\left.\mathrm{C}_{16: 0}\right]$ and physiological and biochemical tests supported the affiliation of the novel strains to the genus Marinospirillum as members of a novel species, for which the name Marinospirillum celere

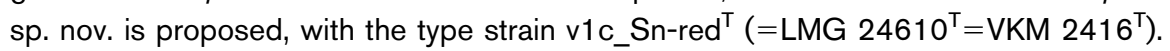

The genus Marinospirillum was created by Satomi et al. (1998) and at present it comprises four species: Marinospirillum minutulum (Watanabe, 1959; Satomi et al., 1998; type species of the genus), Marinospirillum megaterium (Satomi et al., 1998), Marinospirillum alkaliphilum (Zhang et al., 2002) and Marinospirillum insulare (Satomi et al., 2004). All species that belong to this genus are motile, helical, halophilic and Gram-negative. Organotrophic growth occurs on complex organic substrates such as yeast extract and peptone and on organic acids. Carbohydrates are not utilized. Sorokin et al. (2007) isolated an alkaliphilic strain, Marinospirillum sp. ANLisoa, utilizing amides and carboxylic acids in an isobutyronitrile-degrading consortium, but this strain was not validly described as representing a novel species.

Strain v1c_Sn-red ${ }^{\mathrm{T}}$ was isolated from a combined watersediment slurry sample taken from a hot spring $\left(40{ }^{\circ} \mathrm{C}\right.$, $\mathrm{pH}$ 9.3, salinity $25 \mathrm{~g} \mathrm{l}^{-1}$ ) on Paoha island on Mono Lake

The GenBank/EMBL/DDBJ accession number for the 16S rRNA gene sequence of strain v1c_Sn-red ${ }^{\top}$ is EU375807.
(CA, USA). Strain Spir-10 was isolated from a water sample (10 m depth, $\mathrm{pH} 9.5$, salinity $90 \mathrm{~g} \mathrm{l}^{-1}$ ) of Mono Lake. Samples were collected in August 2000. Subsamples $(1 \mathrm{ml})$ were inoculated into $20 \mathrm{ml}$ aerobic medium containing $\left(\mathrm{l}^{-1}\right)$ : $\mathrm{KH}_{2} \mathrm{PO}_{4}, 0.5 \mathrm{~g} ; \mathrm{NH}_{4} \mathrm{Cl}, 0.5 \mathrm{~g} ; \mathrm{KCl}$, $0.5 \mathrm{~g} ; \mathrm{NaCl}, 25 \mathrm{~g} ; \mathrm{Na}_{2} \mathrm{SO}_{4}, 0.5 \mathrm{~g} ; \mathrm{MgSO}_{4} \cdot 7 \mathrm{H}_{2} \mathrm{O}, 0.2 \mathrm{~g}$; yeast extract, $1 \mathrm{~g}$; peptone, $2 \mathrm{~g}$; trace element solution, $1 \mathrm{ml}$ (Pfennig \& Lippert, 1966); vitamin $\mathrm{B}_{12}, 15 \mu \mathrm{g}$. After autoclaving, $0.05 \mathrm{~g} \mathrm{CaCl}_{2} \cdot 2 \mathrm{H}_{2} \mathrm{O} \mathrm{l}^{-1}, 5 \mathrm{~g} \mathrm{NaHCO}_{3} \mathrm{l}^{-1}$ and $5 \mathrm{~g} \mathrm{Na}_{2} \mathrm{CO}_{3} \mathrm{l}^{-1}$ were added from sterile ( $10 \%$, w/v) stock solutions. Enrichment cultures of the strains were incubated at $40{ }^{\circ} \mathrm{C}\left(\right.$ vlc_Sn-red $\left.{ }^{\mathrm{T}}\right)$ or $25{ }^{\circ} \mathrm{C}($ Spir-10). For strain isolation, samples of water were transferred onto plates that contained $2 \%$ agar. Growth was followed by monitoring the increase in $\mathrm{OD}_{550}$ in Hungate tubes (anaerobically) or in plain tubes (aerobically). All runs were done in duplicate. The $\mathrm{pH}$ was adjusted to 9.5 by varying the amounts of $\mathrm{NaHCO}_{3}$ and $\mathrm{Na}_{2} \mathrm{CO}_{3}$ and addition of $1 \mathrm{M}$ $\mathrm{HCl}$ and $1 \mathrm{M} \mathrm{NaOH}$. After determination of optimal growth conditions, both strains were cultivated at $35{ }^{\circ} \mathrm{C}$, $\mathrm{pH} 9.5$ and $2 \% \mathrm{NaCl}(\mathrm{w} / \mathrm{v})$. Substrate-utilization tests were 
performed at optimal temperature and in a $\mathrm{pH}$-optimal carbonate-buffered medium of the following composition: mineral stock plus vitamin solution were the same as above; yeast extract, $0.05 \mathrm{~g} \mathrm{l}^{-1}$; substrate, $1 \mathrm{~g} \mathrm{l}^{-1}$. All substrates were prepared as anaerobic stock solutions in distilled water. Reduction of various inorganic compounds was tested anaerobically on a medium containing pyruvate, peptone and yeast extract (all at $1 \mathrm{~g} \mathrm{l}^{-1}$ ) as described previously (Gorlenko et al., 2004). Poly- $\beta$-hydroxybutyrate accumulation, catalase and oxidase tests, casein, gelatin, hippurate and starch hydrolysis and production of DNase, RNase, urease, lipase, phosphatase, indole and $\mathrm{H}_{2} \mathrm{~S}$ were determined as described by Gerhardt et al. (1994).

Gram staining was performed as described by Gerhardt et al. (1994). Cell morphology was observed under an Olympus BX-41 phase-contrast microscope at $\times 1000$ with cells grown overnight. Micrographs were taken by C-7070 (Olympus) photo attachment on slides coated with $1 \%(\mathrm{w} / \mathrm{v})$ ultrapure agar. The fine structure of cells was studied after fixation of cells with a $1 \%(\mathrm{w} / \mathrm{v})$ solution of $\mathrm{OsO}_{4}$ by the method of Ryter \& Kellenberger (1958). Ultrathin sections were obtained on an LKB-NOVA ultramicrotome and contrasted with a $2 \%(\mathrm{w} / \mathrm{v})$ aqueous solution of uranyl acetate with subsequent treatment with lead citrate (Reynolds, 1963). A JEM-100CXII electron microscope was used at magnifications of $\times 20000-27000$. Negative staining of cells was achieved with $0.1 \%$ uranyl acetate and cells were examined under a transmission electron microscope. Membrane fatty acids were extracted from freeze-dried cells with methanol/ chloroform and analysed by GC-MS as described by Zhilina et al. (1997). Analysis of isoprenoid quinones was performed as described by Collins (1985).
DNA was isolated according to Marmur (1961). The G + C content was determined by the thermal-denaturation method of Marmur \& Doty (1962). DNA-DNA hybridization was performed spectrophotometrically and initial renaturation rates were recorded as described by De Ley et al. (1970). Genomic DNA extraction and PCR-mediated amplification of the 16S rRNA gene were done as described by Rainey et al. (1996). PCR products were sequenced by using a CEQ DTCS kit and run on a CEQ 2000XL DNA sequencing system (Beckman-Coulter). The sequences were aligned by using the CLUSTAL_X software (Thompson et al., 1997). An evolutionary-distance matrix was calculated by using the algorithm of Jukes \& Cantor (1969). The phylogenetic tree was constructed by using the TREECON package (Van de Peer \& De Wachter, 1994) and the neighbour-joining algorithm (Saitou \& Nei, 1987). Bootstrap analyses were based on 500 resamplings.

Physiological and biochemical characteristics of the strains studied are listed in the species description and in Table 1. Both strains require $\mathrm{NaCl}$, with growth being observed at $\mathrm{NaCl}$ concentrations of $0.5-12 \%(\mathrm{w} / \mathrm{v})$ with an optimum at $2 \%$ for both strains. Growth of both strains was seen at $13-55{ }^{\circ} \mathrm{C}$, with a wide temperature optimum of $35-45{ }^{\circ} \mathrm{C}$. The $\mathrm{pH}$ range for growth of both strains is $8.0-10.5$, with an optimum at 9.5. Best growth occurred on caprilate (up to $3 \times 10^{8}$ cells $\mathrm{ml}^{-1}$ ). The shortest doubling time on caprilate-containing medium under optimal conditions was $20 \mathrm{~min}$. At the early stages of development, cells were motile with a swimming speed of up to $60 \mu \mathrm{m} \mathrm{s}^{-1}$. After about 4 days cultivation, thin-walled coccoid bodies are observed, but no spores are produced. In old cultures, cells become shorter and thinner and a protuberance arises from

Table 1. Characteristics of Marinospirillum species and strain v1c_Sn-red ${ }^{\top}$

Strain designations: 1, v1c_Sn-red ${ }^{\mathrm{T}}$ (data from this study); 2, M. alkaliphilum Z4 ${ }^{\mathrm{T}}$ (data from Zhang et al., 2002); 3, M. minutulum ATCC 19193 ${ }^{\mathrm{T}}$ (Watanabe, 1959; Satomi et al., 1998); 4, M. megaterium JCM 10129 ${ }^{\mathrm{T}}$ (Satomi et al., 1998); 5, M. insulare $\mathrm{K}^{\mathrm{T}}$ (Satomi et al., 2004). +, Positive; -, negative; (+), weakly positive; ND, no data; Mi, microaerophilic; Ae, aerophilic.

\begin{tabular}{|c|c|c|c|c|c|}
\hline Characteristic & 1 & 2 & 3 & 4 & 5 \\
\hline Cell diameter $(\mu \mathrm{m})$ & $0.2-0.4$ & $0.2-0.3$ & $0.3-0.4$ & $0.8-1.2$ & $0.1-0.2$ \\
\hline Oxygen requirement & Ae & Ae & Ae & Mi & Ae \\
\hline \multicolumn{6}{|l|}{ Temperature for growth $\left({ }^{\circ} \mathrm{C}\right)$} \\
\hline Range & $13-55$ & $8-49$ & $11-37$ & $4-25$ & $4-37$ \\
\hline \multicolumn{6}{|l|}{$\mathrm{pH}$ for growth } \\
\hline Range & $8.0-10.5$ & $7.0-11.0$ & $7.0-10.5$ & $7.5-9.0$ & $6.5-10.0$ \\
\hline Optimum & 9.5 & 9.5 & 9.0 & 8.0 & 8.0 \\
\hline $\mathrm{NaCl}$ range for growth $(\%, \mathrm{w} / \mathrm{v})$ & $0.5-12$ & $0.2-5.0$ & $0.2-8.0$ & $0.5-9.0$ & $0.5-10.0$ \\
\hline Catalase & + & + & + & - or $(+)$ & + \\
\hline Nitrate reduction & - & + & + & - & + \\
\hline
\end{tabular}


the outer membrane at the end of the cell. The protuberance enlarges and eventually forms a single coccoid body as the helical cell is absorbed (Fig. 1). Similarities in phenotypic characteristics support the inclusion of the studied strains in the genus Marinospirillum. However, the new strains clearly differed from other species by a higher growth-temperature range and optimum and an inability to grow at $\mathrm{pH}$ values $<8.0$.

Strain vlc_Sn-red ${ }^{\mathrm{T}}$ contains ubiquinones that consist mainly of Q8. Menaquinone and methylmenaquinone were not detected. Other Marinospirillum species also have Q8 as the major isoprenoid quinone (Satomi et al., 1998, 2004; Zhang et al., 2002). The fatty acid profile of strain v1c_Sn-red ${ }^{\mathrm{T}}$ is composed of $\mathrm{C}_{18: 1}(\mathrm{n}-7)(48.52 \%), \mathrm{C}_{16: 0}$ $(36.22 \%), \mathrm{C}_{16: 1}(\mathrm{n}-7)(8.05 \%), \mathrm{C}_{14: 1}(\mathrm{n}-3)(3.16 \%)$ and $\mathrm{C}_{14: 0}(1.07 \%)$. This novel strain shows a combination of fatty acids found in other species of the genus Marinospirillum.

A DNA-DNA hybridization experiment revealed that the new isolates are related closely to each other (95\% DNA relatedness), suggesting that they belong to the same species. The G $+\mathrm{C}$ contents of the new isolates v1c_Sn-red ${ }^{\mathrm{T}}$ and Spir-10 were respectively 52.3 and $52.1 \mathrm{~mol} \%$, i.e. 5$10 \mathrm{~mol} \%$ higher than those of other Marinospirillum species. Strains v1c_Sn-red ${ }^{\mathrm{T}}$ and Spir-10 have a high level of $16 \mathrm{~S}$ rRNA gene sequence similarity to each other $(99.6 \%)$ and form a stable phylogenetic cluster, with a

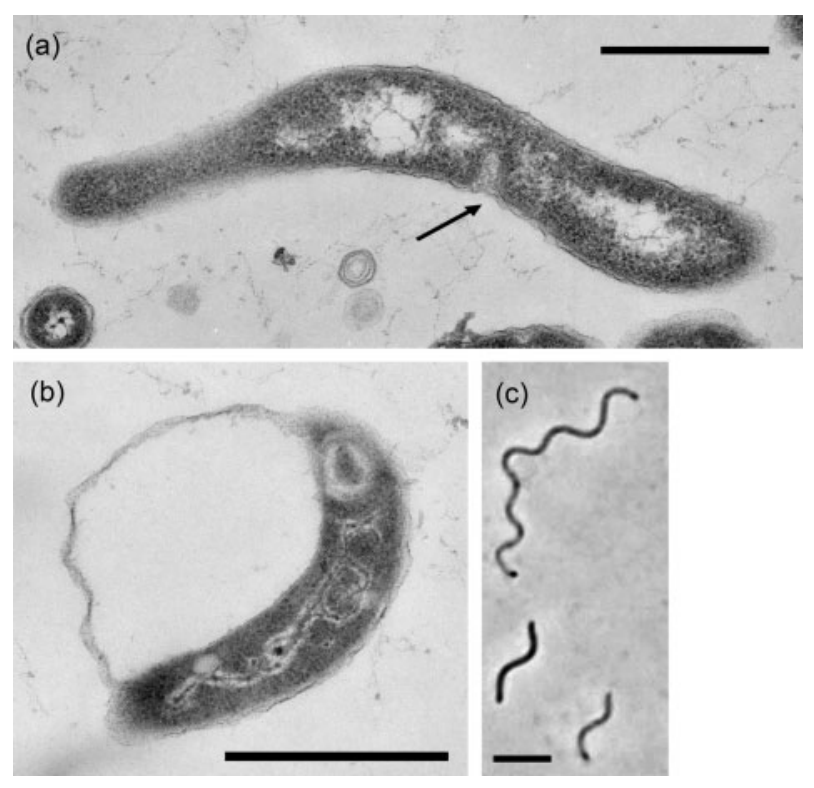

Fig. 1. $(a, b)$ Electron micrographs of ultrathin-sectioned cells of strain v1c_Sn-red ${ }^{\top}$ from (a) the exponential-growth phase, showing the invagination of the cell membrane during cell division (arrow), and (b) the stationary-growth phase, showing the formation of a coccoid body. (c) Phase-contrast photograph of cells of strain v1c_Sn-red ${ }^{\top}$ from the exponential-growth phase. Bars, $0.5 \mu \mathrm{m}(\mathrm{a}, \mathrm{b}) ; 2 \mu \mathrm{m}$ (c). bootstrap value of $100 \%$, within the genus Marinospirillum (Fig. 2). Sequence-similarity calculations after neighbourjoining analysis indicated that the closest relatives of strain v1c_Sn-red ${ }^{\mathrm{T}}$ were $M$. alkaliphilum $\mathrm{Z}^{\mathrm{T}}(95.0 \%), M$. minutulum ATCC $19193^{\mathrm{T}}(92.7 \%)$, M. megaterium JCM $10129^{\mathrm{T}}(91.8 \%)$ and $M$. insulare $\mathrm{K}^{\mathrm{T}}(91.8 \%)$. Lower sequence similarities $(<89.5 \%)$ were found with other Gram-negative spirilla.

On the basis of the low 16S rRNA gene sequence-similarity values $(<95 \%)$ to other species of the genus Marinospirillum, a higher $\mathrm{G}+\mathrm{C}$ content and their distinct physiological characteristics compared with other species of this genus, strains vlc_Sn-red ${ }^{\mathrm{T}}$ and Spir-10 represent a novel species. We propose the name Marinospirillum celere sp. nov. for this taxon, with the type strain vlc_Sn-red ${ }^{\mathrm{T}}$.

Sequence-similarity calculations, a higher $\mathrm{G}+\mathrm{C}$ content and higher $\mathrm{pH}$ and temperature optima show that both novel strains are related more closely to M. alkaliphilum than to other Marinospirillum species. Although $M$. minutulum, M. megaterium and $M$. insulare were isolated previously from an ocean environment and artificial brines (Satomi et al., 1998, 2004), the novel strains and $M$. alkaliphilum were isolated from soda lakes. The last two species could form a novel genus in the family Oceanospirillaceae, but we believe that it is better to wait until more haloalkaliphilic Marinospirillum species have been isolated before naming this taxon.

\section{Description of Marinospirillum celere sp. nov.}

Marinospirillum celere (ce'le.re. L. neut. adj. celere rapid, indicating the rapid growth on nutrient media and high motility).

Gram-negative, helical, aerobic and chemoheterotrophic. Motile by bipolar flagella. Cells are $0.2-0.4 \mu \mathrm{m}$ in diameter and 1.4-15 $\mu \mathrm{m}$ in length. Coccoid bodies are observed after

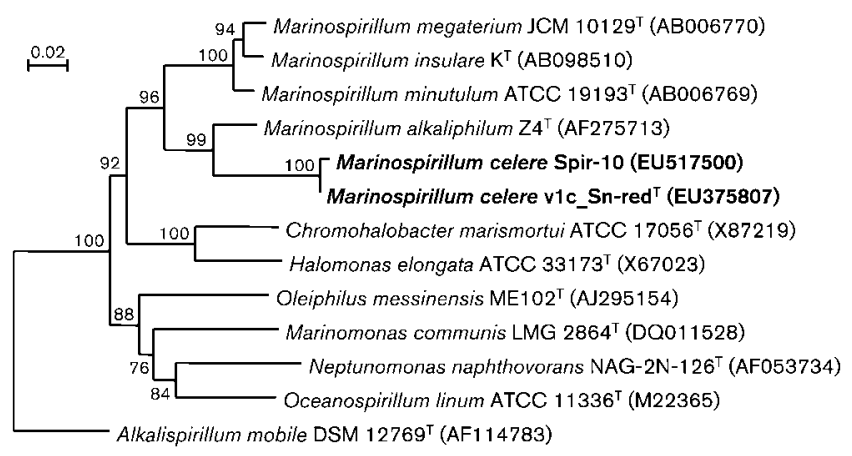

Fig. 2. Phylogenetic tree constructed by the neighbour-joining method based on 16S rRNA gene sequences of the new isolates v1c_Sn-red ${ }^{\top}$ and Spir-10 and type strains of related species. Bar, 0.02 genetic distance. Numbers at nodes are bootstrap-support values (percentages of 500 resamplings). The type strain of Alkalispirillum mobile was used as the outgroup. 
4 days culture, but no spores are produced. The helix type is counterclockwise. Halophilic, $\mathrm{NaCl}$ is required for growth; growth occurs at $\mathrm{NaCl}$ concentrations of $0.5-$ $12 \%(\mathrm{w} / \mathrm{v})$ and is optimal at $2 \% \mathrm{NaCl}$. Temperature range for growth is $13-55^{\circ} \mathrm{C}$; optimal temperature is $35-45^{\circ} \mathrm{C}$. Alkaliphilic, $\mathrm{pH}$ range for growth is $8.0-10.5$; optimal $\mathrm{pH}$ is 9.5. Colonies are circular, smooth, opalescent and $1 \mathrm{~mm}$ in diameter after overnight culture. Catalase- and oxidasepositive. Able to utilize caprilate, acetate, pyruvate, lactate, Casamino acids, yeast extract and peptone. D-Ribose, Dglucose, sucrose, rhamnose, cellulose, glycerol, citrate, glycolate and cysteine are not utilized. Casein, gelatin, hippurate and starch are not hydrolysed. Indole, $\mathrm{H}_{2} \mathrm{~S}$, DNase, RNase, phosphatase, urease and lipase are not produced. Reduction of thiosulfate, sulfate, sulfite, polysulfide, sodium selenite, ferric citrate, ferric hydroxide and elemental sulfur is not observed. Nitrate reduction and denitrifying activity are negative. Does not grow autotrophically on $\mathrm{H}_{2}+\mathrm{CO}_{2}$. Intracellular poly- $\beta$-hydroxybutyrate is formed. Isoprenoid quinone type is Q8. Whole-cell fatty acids consist mainly of $\mathrm{C}_{18: 1}(\mathrm{n}-7)$ and $\mathrm{C}_{16: 0}$. DNA G $+\mathrm{C}$ content of the type strain is $52.3 \mathrm{~mol} \%$.

The type strain is vlc_Sn-red ${ }^{\mathrm{T}}\left(=\mathrm{LMG} 24610^{\mathrm{T}}=\mathrm{VKM}\right.$ $\left.2416^{\mathrm{T}}\right)$, isolated from Mono Lake (CA, USA).

\section{Acknowledgements}

This work was supported by the Russian Foundation for Basic Research (grant 07-04-00651), the Programs of the Russian Academy of Sciences 'Molecular and Cell Biology' and 'Origin and Evolution of Biosphere' and the Russian Science Support Foundation. This research was carried out in part at the Jet Propulsion Laboratory, California Institute of Technology, under a contract with the National Aeronautics and Space Administration. We also thank Anatoly Lysenko for determination of the DNA G + C content, Georgy Osipov for fatty acid analysis and Boris Baskunov for determination of quinone composition.

\section{References}

Collins, M. D. (1985). Analysis of isoprenoid quinones. Methods Microbiol 18, 329-366.

De Ley, J., Cattoir, H. \& Reynaerts, A. (1970). The quantitative measurement of DNA hybridization from renaturation rates. Eur $J$ Biochem 12, 133-142.

Gerhardt, P., Murray, R. G. E., Wood, W. A. \& Krieg, N. R. (editors) (1994). Methods for General and Molecular Bacteriology. Washington, DC: American Society for Microbiology.

Gorlenko, V., Tsapin, A., Namsaraev, Z., Teal, T., Tourova, T., Engler, D., Mielke, R. \& Nealson, K. (2004). Anaerobranca californiensis sp nov., an anaerobic, alkalithermophilic, fermentative bacterium isolated from a hot spring on Mono Lake. Int J Syst Evol Microbiol 54, 739-743.
Jukes, T. H. \& Cantor, C. R. (1969). Evolution of protein molecules. In Mammalian Protein Metabolism, vol. 3, pp. 21-132. Edited by H. N. Munro. New York: Academic Press.

Marmur, J. (1961). A procedure for the isolation of deoxyribonucleic acid from microorganisms. J Mol Biol 3, 208-218.

Marmur, J. \& Doty, P. (1962). Determination of the base composition of deoxyribonucleic acid from its thermal denaturation temperature. J Mol Biol 5, 109-118.

Pfennig, N. \& Lippert, K. D. (1966). Über das Vitamin $B_{12}$-Bedürfnis phototropher Schwefelbakterien. Arch Microbiol 55, 245-256 (in German).

Rainey, F. A., Ward-Rainey, N., Kroppenstedt, R. M. \& Stackebrandt, E. (1996). The genus Nocardiopsis represents a phylogenetically coherent taxon and a distinct actinomycete lineage: proposal of Nocardiopsaceae fam. nov. Int J Syst Bacteriol 46, 1088-1092.

Reynolds, E. S. (1963). The use of lead citrate at high $\mathrm{pH}$ as an electron-opaque stain in electron microscopy. J Cell Biol 17, 208-212.

Ryter, A. \& Kellenberger, E. (1958). Etude au microscope electronique de plasmas contenant de l'acide desoxyribonucleique. $Z$ Naturforsch [B] 13b, 597-605 (in French).

Saitou, N. \& Nei, M. (1987). The neighbour-joining method: a new method for reconstructing phylogenetic trees. Mol Biol Evol 4, 406425.

Satomi, M., Kimura, B., Hayashi, M., Shouzen, Y., Okuzumi, M. \& Fujii, T. (1998). Marinospirillum gen. nov., with descriptions of Marinospirillum megaterium sp. nov., isolated from kusaya gravy, and transfer of Oceanospirillum minutulum to Marinospirillum minutulum comb. nov. Int J Syst Bacteriol 48, 1341-1348.

Satomi, M., Kimura, B., Hayashi, M., Okuzumi, M. \& Fujii, T. (2004). Marinospirillum insulare sp. nov., a novel halophilic helical bacterium isolated from kusaya gravy. Int J Syst Evol Microbiol 54, 163-167.

Sorokin, D. Y., van Pelt, S., Tourova, T. P. \& Muyzer, G. (2007). Microbial isobutyronitrile utilization under haloalkaline conditions. Appl Environ Microbiol 73, 5574-5579.

Thompson, J. D., Gibson, T. J., Plewniak, F., Jeanmougin, F. \& Higgins, D. G. (1997). The CLUSTAL_X windows interface: flexible strategies for multiple sequence alignment aided by quality analysis tools. Nucleic Acids Res 25, 4876-4882.

Van de Peer, Y. \& De Wachter, R. (1994). TREeCON for Windows: a software package for the construction and drawing of evolutionary trees for the Microsoft Windows environment. Comput Appl Biosci 10, 569-570.

Watanabe, N. (1959). On four new halophilic species of Spirillum. Bot Mag Tokyo 72, 77-86.

Zhang, W., Xue, Y., Ma, Y., Grant, W. D., Ventosa, A. \& Zhou, P. (2002). Marinospirillum alkaliphilum sp. nov., a new alkaliphilic helical bacterium from Haoji soda lake in Inner Mongolia Autonomous Region of China. Extremophiles 6, 33-37.

Zhilina, T. N., Zavarzin, G. A., Rainey, F. A., Pikuta, E. N., Osipov, G. A. \& Kostrikina, N. A. (1997). Desulfonatronovibrio hydrogenovorans gen. nov., sp. nov., an alkaliphilic, sulfate-reducing bacterium. Int J Syst Bacteriol 47, 144-149. 